\title{
The Implementation of OBE-Based Management Accounting Learning
}

\author{
Riwayadi $^{1 * *}$ Denny Yohana ${ }^{2}$
}

\author{
${ }^{1}$ Faculty of Economics, Universitas Andalas, Padang, West Sumatera 25163, Indonesia \\ ${ }^{2}$ Faculty of Economics, Universitas Andalas, Padang, West Sumatera 25163, Indonesia \\ *Corresponding author. Email: riwayadi@eb.unand.ac.id
}

\begin{abstract}
This research aims to evaluate the effectiveness of the implementation of OBE-based management accounting learning. The research type is applied research. The population is the students who are taking management accounting courses This research uses census sampling. It is found that OBE-based learning motivates students to optimize the achievement of the ELOs. It improves the results of formative assessments and final grades.

Students agree that CELOs has been adequate to build their soft skills and hard skills. Soft skills that should be possessed by a management accountant are: (1) able to have logical, critical, systematic, and innovative thinking by applying the concepts of management accounting, (2) able to work in teams, (3) able to present information and express ideas clearly, both verbally and in writing. They also agree that quizzes, group assignments and presentations, discussion forums, midterm exam, and final exam are required to help them to achieve LELOs.
\end{abstract}

Keywords: Outcome-based education (OBE), formative assessment, program's expected learning outcomes, course's expected learning outcomes, lesson's expected learning outcomes

\section{INTRODUCTION}

\subsection{Higher Education National Standard}

Graduates should have four competencies referring to National Standard for Higher Education: Value \& Attitude, Knowledge Proficiency, Work Skill Competency, and Managerial Skills [10]. Value and attitude are correct and cultured behavior as a result of internalization and actualization of values and norms reflected in spiritual and social life through the learning process, student work experience, research, and/or community service related to learning. Knowledge Proficiency is the systematic mastery of concepts, theories, methods, and/or philosophies obtained through reasoning in the learning process, student work experience, research, and/or community service related to learning. Student work experiences are obtained from activities in a certain field for a certain period, in the form of job training, practical work, fieldwork practices, or other similar activities. Skills are the ability to perform work using concepts, theories, methods, materials, and/or instruments, which are obtained through learning, student work experience, research, and/or community service related to learning. Skills consist of (a) General skills (managerial skills), that is, general work abilities of each graduate should have, to ensure the equality of graduate abilities according to program level and type of higher education; and (b). Specific skills (work skill competencies), that is, specific work abilities of each graduate should havethat is suitable for the program's scientific field.

\subsection{Outcome-Based Education (OBE)}

Outcomes-based education (OBE) can be described as a way in which curriculum is defined, organized, and directed based on all the things that learners would learn and demonstrate successfully when they complete the study program. The focus of OBE is on the results of learning, where the knowledge, skills, and attitudes including habits of mind, the learners who are expected to learn are clearly identified and expressed as expected learning outcomes [1].

Expected Learning Outcomes (ELOs) should be formulated consisting of the program's expected learning outcomes, the course's expected learning outcomes (CELOs), and the lesson's expected learning outcomes (LELOs). Cognitive competencies referring to Bloom Taxonomy have 6 levels: remembering, understanding,applying, analyzing, evaluating, and creating (13). Curriculum, student assessment method, and learning \& teaching strategy should align to the 
expected learning outcomes (constructive alignment) as seen in Figure 1.

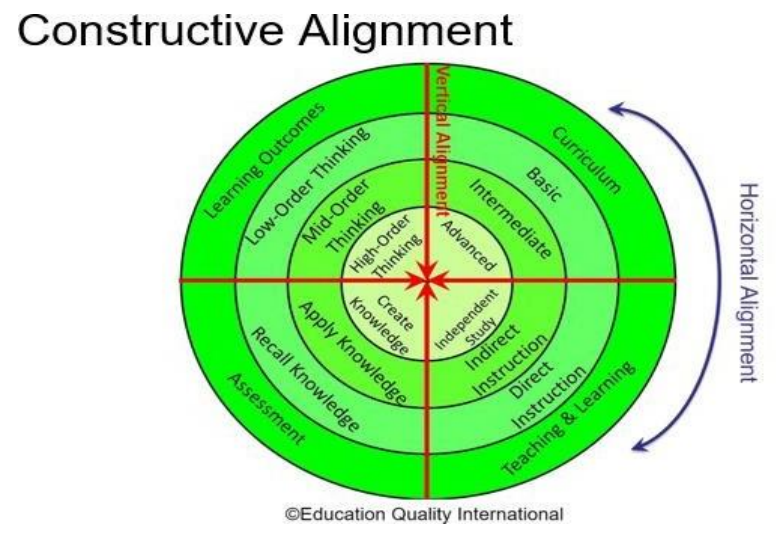

Figure 1 Constructive Alignment

The study program that has implemented OBE Approach should develop outcome-based curriculum (OBC), outcome-based learning and teaching (OBT), and outcome-based assessment as seen in Figure 2.

\section{Outcome Based Education}

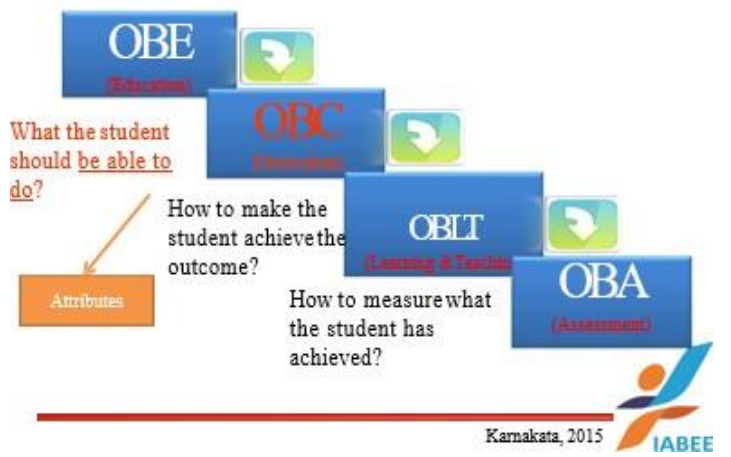

Figure 2 Outcome-Based Education

OBE focuses on what we wish to achieve from our graduates. The achievement of the Program's expected learning outcomes should be measured using tracer study to users after graduates work for $3-5$ years. The result of the tracer study should then be used as feedback for the improvement of the Program's expected learning outcomes.

\subsection{Blended Learning}

Blended Learning is one of the learning methods that harmoniously combines the advantages of face-toface (offline) with the advantages of online learning in order to achieve graduates' learning outcomes [8]. Distance learning activities should be more dominant self-directed and collaborative asynchronous, not virtual synchronous. One of the blended learning models is flipped classroom learning. Flipped classroom learning is a learning model by minimizing the number of face- to-face learning and maximizing online activities, either in the form of virtual synchronous or asynchronous. This strategy utilizes technology that supports learning materials that can be accessed online and offline anytime and anywhere. Classroom learning time is used by students to collaborate with colleagues on projects, practice skills, and receive feedback on their progress.

Flipped classroom learning can be interpreted as a learning model that changes direct instruction learning in a face to face classroom to a self-directed classroom and transforms into a dynamic and interactive learning environment where the lecturer guides students to apply concepts and link the learning materials well [12]. In the direct instruction learning model, the lecturer explains learning materials in the classroom and asks the students to solve the homework. In a flipped classroom, the classroom is flipped. The students have to learn the learning materials given by the lecturer. In a face-to-face classroom, much learning time is used for assessments, discussions, and exercises.

\section{RESEARCH METHOD}

This research is applied research that emphasizes practical problem solving directed to answer the specific questions for policy development, action, or particular performance [5]. The research is evaluation research that is used for the evaluation of the effectiveness of an action, activity, or program [5]. This research is a qualitative approach that uses data in the form of written or verbal sentences, behavior, phenomena, events, knowledge, or the objects of the research [7]. Qualitative research is concerned with the explanation of social phenomena. It aims to help us to understand the world in which we live and why things are the way they are (4].

The subject of the research is all Universitas Andalas's accounting students who are taking management accounting, either regular program or international program. The population is all accounting students who are taking management accounting in the second semester of 2019/2020 for the classes of IV/A1, IV/A2, IV/A3, IVA4, and IV/Int.A (160 students). Samples are 80 students consisting of 40 students for IV/A1 class and 40 students for IV/Int.A class.

This research uses primary data that are collected through observation and survey. Observation is conducted when the students answer quizzes using Kahoot's online learning game or Universitas Andalas's learning management system, which is called ilearn. 
The observation aims to evaluate the achievement of the course's and lesson's expected learning outcomes. The survey is conducted by distributing questionnaires to students on the final exam schedule before students answer the question in order to be fair. The questionnaire is developed using 5 Likert scales: 5 (highly agree), 4 (agree), 3 (neutral), 2 (not agree), and 1 (highly not agree).

Data analysis is conducted by (1) tabulating the questionnaire, (2) calculating the average score of each question by dividing the total score by the total number of respondents, and (3) drawing the conclusion.

Besides the questionnaire, the success of the implementation of OBE-based accounting management learning is also assessed by comparing the final grade and quiz grades before and after the implementation.

\section{THE EFFECTIVENESS OF THE IMPLEMENTATION OF OBE-BASED}

\section{MANAGEMENT ACCOUNTING LEARNING}

The effectiveness of the implementation of OBEbased management accounting learning is measured by formative assessments and summative assessment grades covering assignments, presentations, discussions, quizzes, midterm exam, and final exam. Assignments are used to measure psychomotor, cognitive, affective (teamwork, creative and innovative) performance. Presentations and discussions are used to measure affective performance (critical thinking, and teamwork)

\subsection{Formative Assessment}

Kahoot's online learning games were used for formative assessments and the results are presented on Tabel 1 below:

Table 1The results of formative assessment using Kahoot's online learning game

\begin{tabular}{|l|l|c|c|}
\hline No. & \multicolumn{1}{|c|}{ Topic } & $\mathbf{2}^{\text {nd }}$ Semester of 2018/2019 & $\mathbf{2}^{\text {nd }}$ Semester of 2019/2020 \\
\hline 1. & Introduction to management accounting & $73,24 \%$ & $63,3 \%$ \\
\hline 2. & Cost concepts & $75,07 \%$ & $76,07 \%$ \\
\hline 3. & Standard costing & $66,51 \%$ & $74,13 \%$ \\
\hline 4. & Variable costing & $58,05 \%$ & $70,40 \%$ \\
\hline 5. & CVP analysis - single product setting & $64,71 \%$ & $71,50 \%$ \\
\hline & Average & $67,52 \%$ & $71,08 \%$ \\
\hline
\end{tabular}

Table 1 above shows that the implementation of OBE- based learning increases the number of students who can answer the Kahoot's quizzes. Average number of students who can answer quizzes $67,52 \%$ before the implementation of OBE-based learning and increase to 71,08 after the implementation of OBE-based learning or increase by $3,56 \%$.

\subsection{Final grades}

The comparison of final grades before and after the implementation of OBE-based learning is presented in Table 2.
Table 2 The Comparison of Final Grade Before and After the Implementation of OBE-Based Leaning

\begin{tabular}{|l|c|c|}
\hline $\begin{array}{l}\text { Final } \\
\text { Grades }\end{array}$ & $\begin{array}{c}\text { Before the } \\
\text { Implementation of } \\
\text { OBE-Based Learning }\end{array}$ & $\begin{array}{c}\text { After the } \\
\text { Implementation of } \\
\text { OBE-Based Learning }\end{array}$ \\
\hline A & $25 \%$ & $27,5 \%$ \\
\hline A- & $13 \%$ & $42,5 \%$ \\
\hline B+ & $23 \%$ & $20 \%$ \\
\hline B & $25 \%$ & $7,5 \%$ \\
\hline B- & $13 \%$ & $2,5 \%$ \\
\hline C+ & $1 \%$ & - \\
\hline C & $0 \%$ & - \\
\hline Total & $100 \%$ & $100 \%$ \\
\hline
\end{tabular}

Table 2 above shows that there was a significant improvement in final grades before and after the implementation of OBE-Based Learning. This improvement indicates the achievement of the course's ELOs. Students who got grade A and A-38\% before 
the implementation of OBE-based learning, and increase significantly to $70 \%$ after the implementation of OBE-based learning. An increase in grade A ratio automatically reduces the grade $\mathrm{B}$ ratio and even no student got grade C. The significant improvement of final grades is caused by the high motivation of students to achieve the CELOs and LELOs. In output-based learning, lecturers just focus on the achievement of the targeted number of class meetings so that it does not encourage high motivation of students to achieve their competencies.

\subsection{Questionnaire Results}

\subsubsection{Program's Expected Learning Outcomes (PELOs)}

Table 3 Questionnaire Results of PELOs

\begin{tabular}{|l|l|c|}
\hline No. & \multicolumn{1}{|c|}{ Question } & $\begin{array}{c}\text { Average } \\
\text { Score }\end{array}$ \\
\hline 1. & $\begin{array}{l}\text { Accounting Study Program has socialize } \\
\text { PELOs }\end{array}$ & 4,11 \\
\hline 2. & $\begin{array}{l}\text { I know PELOs from the Semester } \\
\text { Learning Plan that is given by the lecturer } \\
\text { in the beginning class meeting of the } \\
\text { semester }\end{array}$ & 4,23 \\
\hline 3. & $\begin{array}{l}\text { Lecturers explain ELOs that should be } \\
\text { possessed by graduates }\end{array}$ & 4,23 \\
\hline 4. & I understand well about all PELOs & 3,64 \\
\hline 5. & $\begin{array}{l}\text { PELOs is always my concern to study } \\
\text { each course that I take }\end{array}$ & 3,94 \\
\hline & Average Score & 4,03 \\
\hline
\end{tabular}

Table 3 above shows that PELOs have been socialized by Accounting Study Program and also explained by lecturers. Students also understand about PELOs and strive to achieve it as indicated by an average score of 4,03 .

\subsubsection{Course's Expected Learning Outcomes (CELOs)}

Table 4 Questionnaire Results of CELOs

\begin{tabular}{|l|l|c|}
\hline No. & \multicolumn{1}{|c|}{ Question } & $\begin{array}{c}\text { Average } \\
\text { Score }\end{array}$ \\
\hline 1. & $\begin{array}{l}\text { I know that CELOs should be achieved } \\
\text { by students after completing this course }\end{array}$ & 4,42 \\
\hline 2. & $\begin{array}{l}\text { According to me, soft skills (CELO 2 - } \\
\text { 4) is needed by the management } \\
\text { accountant }\end{array}$ & 4,36 \\
\hline 3. & $\begin{array}{l}\text { According to me hard skill (CELO 1) } \\
\text { and soft skill (CELO 2 - 4) have been } \\
\text { adequate for a management accountant }\end{array}$ & 4,11 \\
\hline 4. & I strive optimally to achieve this CELOs & 4,51 \\
\hline & Average Score & 4,35 \\
\hline
\end{tabular}

Table 4 above shows that students understand the competencies that should be possessed as a management accountant. According to them, CELOs has been adequate to build their soft skills and hard skills. CELOs has motivated students to learn effectively as indicated by average score 4,35 . Students agree that soft skills that should be possessed by a management accountant are: (1) able to have logical, critical, systematic, and innovative thinking by applying the concepts of management accounting, (2) able to work in teams, (3) Able to present information and express ideas clearly, both verbally and in writing.

\subsubsection{Lesson's Expected Learning Outcomes (LELOs)}

Table 5 Questionnaire Results of LELOs

\begin{tabular}{|c|c|c|}
\hline No. & Question & $\begin{array}{l}\text { Average } \\
\text { Score }\end{array}$ \\
\hline 1. & $\begin{array}{l}\text { I know that LELOs are the competencies } \\
\text { that I should have for each class meeting }\end{array}$ & 4,19 \\
\hline 2. & $\begin{array}{l}\text { LELOs are always my concern before } \\
\text { having class in the next meeting }\end{array}$ & 3,66 \\
\hline 3. & $\begin{array}{l}\text { I always make sure that I have achieved } \\
\text { LELOs when I learn learning materials } \\
\text { for each class meeting }\end{array}$ & 3,70 \\
\hline 4. & $\begin{array}{l}\text { Learning materials such as video, } \\
\text { PowerPoint, and others are very helpful } \\
\text { for self-directed asynchronous learning } \\
\text { compared to lecture in the classroom } \\
\text { because learning materials can be } \\
\text { repeated as needed }\end{array}$ & 3,91 \\
\hline 5. & $\begin{array}{l}\text { Self-directed asynchronous learning } \\
\text { makes more time for assessment, } \\
\text { discussions, and exercises in the } \\
\text { classroom }\end{array}$ & 3,96 \\
\hline 6. & $\begin{array}{l}\text { Quiz for each class meeting is useful to } \\
\text { motivate the students to self-learn } \\
\text { learning materials effectively }\end{array}$ & 4,28 \\
\hline 7. & $\begin{array}{l}\text { Quiz results are useful as feedbacks for } \\
\text { improvement to optimize the achievement } \\
\text { of LELOs. }\end{array}$ & 4,30 \\
\hline 8. & $\begin{array}{l}\text { Discussion forums are helpful for me to } \\
\text { understand the learning material well }\end{array}$ & 4,02 \\
\hline 9 . & $\begin{array}{l}\text { Discussion forums can be used to achieve } \\
\text { LELO } 1 \text { and } 2\end{array}$ & 4,04 \\
\hline 10. & $\begin{array}{l}\text { Group assignment can help me to apply } \\
\text { the concepts of given learning materials }\end{array}$ & 3,98 \\
\hline 11. & $\begin{array}{l}\text { Group assignment and presentation can be } \\
\text { used to achieve LELO } 1-4\end{array}$ & 3,94 \\
\hline 12. & $\begin{array}{l}\text { Midterm and final exams can be used to } \\
\text { measure the achievement of LELOs and } \\
\text { CELO } 1 \text {. }\end{array}$ & 3,96 \\
\hline \multirow[t]{2}{*}{13.} & $\begin{array}{l}\text { Tutorial class is helpful to improve the } \\
\text { technical skills of management } \\
\text { accounting }\end{array}$ & 3,99 \\
\hline & Average Score & 4,06 \\
\hline
\end{tabular}

Table 5 above shows that the average score of LELOs is 4,06. It means that students understand the LELOs and strive to achieve them. They also understand that quizzes, group assignments and presentations, discussion forums, mid-term exam, and final exam are needed to help them to achieve 
LELOs. They also need a tutorial class to help them to improve their technical skills in management accounting.

\section{CONCLUSION}

OBE focuses on the constructive alignment of PELOs, CELOs, LELOs, curriculum, assessment methods, and teaching and learning strategies. OBEbased learning has proved that CELOs and LELOs can more optimally be achieved as indicated by the results of formative assessment and summative assignment. Students agree that Quizzes, group assignments and presentations, and discussion forums can be used to help them to achieve soft skill competencies. They also agree that the tutorial class is needed to help them to improve the technical skills of management accounting. This research assumes that the input quality of current students is similar to that of previous students.

\section{REFERENCES}

[1] ASEAN University Networks/AUN-QA, Guide to AUN QA Assessment at Program Level, Version 3.0, Bangkok, Thailand:Chulalongkorn University, 2015.

[2] U A.Chaeruman, "Merancang Blended Learning Yang Mengajarkan"in Seminar Nasional dan Kongres Alumni, Universitas Negeri SebelasMaret, Solo, 2013.

[3] Dmayanti, H.Novis, and Sutama,JurnalManajemen Pendidikan, vol. 11, no. 2, pp. 2-8, January 2016.

[4] B. Hancock. An Introduction to Qualitative Research. Trent Focus Group. University of Nottingham, 2002.

[5] N. Indriantoroand B. Supomo, Metodologi Penelitian Bisnis Untuk Akuntansi dan Manajemen, Edisi Pertama, Yogyakarta:BPFE, 1999.

[6] G.B Johnson,Student Perception of the Flipped Classroom, Columbia: The University of British Columbia, 2013.

[7] Moleong, Lexy J. Metode Penelitian Kualitatif, revised edition, Bandung: Remaja Rosdakarya, 2006.

[8] KPT Kementerian Riset dan Teknologi Pendidikan Tinggi (KemenristekDikti) Team, 2018.

[9] PeraturanPresidenRepublik Indonesia Nomor 8 Tahun 2012 tentangKerangkaKualifikasi Nasional Indonesia
[10] Peraturan Menteri Pendidikan dan Kebudayaan No. 73 Tahun 2013 tentang Penerapan Kerangka Kualifikasi Nasional Indonesia Bidang Pendidikan Tinggi

[11] Peraturan Menteri Pendidikan dan Kebudayaan No. 49 Tahun 2014 tentangStandar Nasional Pendidikan Tinggi

[12] Schultz, D., Duffield, S., Rasmussen, C., \&Wageman, J. Effect of the Flipped Classroom Model on Student Performance for Advance Placement High School Chemistry Student. Journal of Chemical Education, (Online), 91 (9), 2014.pp. 1334-1339, (http://pubs.acs.org/doi/abs/10.1021/ed400868x)

[13]R. Utari.Taksonomi Bloom, Apa dan Bagaimana Menggunakannya? Pusdiklat KNPK. 